\title{
Fiberglass reinforced plastic as construction material for Indonesian fishing vessels - challenges and future potential development
}

\author{
I Putu A. Wibawa ${ }^{1, *}$ and Richard W. Birmingham ${ }^{2}$ \\ ${ }^{1}$ Design and Construction Study Program, Politeknik Perkapalan Negeri Surabaya, 60111 Surabaya, \\ Indonesia \\ ${ }^{2}$ Marine, Offshore, and Subsea Technology Research Group, School of Engineering, Newcastle \\ University, 2308 Newcastle upon Tyne, United Kingdom
}

\begin{abstract}
The continuous increase in the use of wood in many sectors and the growing concerns on the sustainability of the forest products has raised serious questions as to the sustainability of wood as a construction material for fishing vessels in Indonesia. Based on the current developments, Fiberglass Reinforced Plastic (FRP) material is potentially the top alternative substitute to wood for building fishing vessels in Indonesia. However, the initiatives to introduce FRP, particularly by the Indonesian government, as alternative construction material still have many problems including that of acceptance by the fishers themselves. The result of the study shows that some aspects that need to be developed for implementing FRP as construction material in the future, including: fishers' knowledge and experiences regarding to FRP as construction material, the suitable design of the FRP fishing vessels for specific fishing communities and proper infrastructure to support the FRP boats industries.
\end{abstract}

\section{Introduction}

As one of the major nations that are engaged in capture fisheries, Indonesia has a very large number of fishing vessels. According to the Indonesian Ministry of Marine Affairs and Fisheries (IMMAF) there were about 625,633 fishing vessels in the entire Indonesian waters in 2014. About $89 \%$ of these were small vessels of up to 5 Gross Tonnage (GT) [1] and employ relatively low level of technology on board [2]. The ability of the Indonesian fishing fleet to be able to support the long-term sustainability of fisheries sector in Indonesia is obviously affected by how the fleet could adapt to the inflexible conditions of finite resources and in the possibilities made available by new technology in the future. According to the existing general condition of the fleet, in addition to low level of technology applied on board, the problems also lies in the choice of the construction material for the fishing vessels following the growing concern with complex environmental and sustainability issues [3]

\footnotetext{
* Corresponding author: putuarta@ppns.ac.id
} 
In addition to wood, the conventional Fiberglass Reinforced Plastic (FRP) material has become more familiar recently as material for building fishing vessels in Indonesia, especially since there are difficulties of obtaining timber with good quality and proper dimensions as required by the traditional fishing boat industries [3]. FRP fishing vessels, over the last few decades, have been gradually introduced into many fishing ports and fishing communities in Indonesia. Mainly through many programmes from the Indonesian government and through various international institutions such as the Food and Agriculture Organization (FAO) of the United Nations (UN). One of those programmes was part of the recovery and mitigation programme after the tsunami disaster in Aceh Province in 2004, as a result of which FRP fishing vessels had been donated to local fishing communities by many countries and international organizations $[4,5]$.

The latest programme that also have been trying to promote FRP for fishing vessels in Indonesia is a programme of the IMMAF to build thousands of units of fishing vessels of 3GT to 30 GT since 2010 for many fishing communities in Indonesia [6]. For the first period of the programme, 2010 - 2014, there were still many wooden fishing vessels granted to local fishing communities. However, for the second period, $2015-2019$, the IMMAF requires the use of FRP materials for all grant vessels. This policy eventually resulted in some problems regarding the production of the vessels and the local fishers' acceptance $[7,8]$.

The lightweight of FRP structure is the main reason for the selection of FRP as alternative material for substituting wood for fishing boats. The FRP boat will give $27 \%$ reduction on the boat lightweight compare to wooden boat [9]. Moreover, it is about $10 \%$ lighter compare to Aluminium boat and about 35\% lighter than steel boat with the same size [10]. However, regardless of the advantages that the FRP material have, the application of this material for fishing vessels in Indonesia are still limited.

Therefore, in order to have an overview about the existing circumstances on the implementation of FRP as alternative material for fishing vessels in Indonesia and to identify the future development required, the field study have been conducted in three fishing communities in Indonesia and the results of this field study are presented in this paper.

\section{Research Method}

The three fishing communities targeted for field study were Brondong and Muncar, both in East Java Province, and Latuhalat which is in Ambon, Maluku Province. Each fishing community has specific characteristics on their fishing practices, such as type of fishing gears, distance to fishing grounds, and length of fishing trips. Each fishing community also has been long established as a recognised centre for capture fisheries in Indonesia.

In order to have complete overviews about the current conditions of fishing vessels in selected fishing communities in term of their construction materials, and of the fishers' perspectives relating to their existing fishing vessels, a total of 73 individual fishers from within the three fishing communities have been directly interviewed. The interviews were undertaken using a semi structured interview format with open-ended questions that allowed the respondents to explain in further detail about their answers. The fishers' understanding of and preferences for the potential alternative technologies for their fishing vessels have been elicited. Their particular views regarding their existing hull material and its virtues and difficulties have been elicited as well.

To support the subsequent analyses of the collected interview results, other local stakeholders have also been interviewed about the existing technology that is incorporated in the local fishing vessels and on any possibilities to apply alternative technology for future local fishing vessels. These related stakeholders were local boatyards, harbour 
masters and local fisheries agencies. Other general observations on the existing local fishing vessels and local boatyards have also been undertaken to compile supporting and complementary data.

\section{Results and Discussion}

\subsection{Fishers' perspectives on FRP fishing vessels}

The results of the in-depth interviews in the three selected fishing communities regarding local fishers' preferences on construction materials can be seen in the bar charts as illustrated in Figure 1. Based on this figure, wood clearly remains as being the main preference used for construction material in the three selected fishing communities.

A mix of responses was ascertained however in the three communities regarding the potential employment of FRP. Further evaluations of the respondents' responses have suggested a possible explanation of the reason for the fishers' refusal or acceptance on FRP as being an alternative material for their fishing vessels. Local fishers' opinions about FRP generally were influenced by the characteristics of the local fishing vessels, their fishing practices and the local fishers' understanding about FRP as a construction material for fishing vessels, which is mostly based on their personal observations or by word of mouth.

The primary concern of the local fishers in Brondong and Muncar that have little or no interest in FRP is in the strength of the FRP material itself. Local fishers, principally those that operate heavy fishing gear, such as purse seine and seine nets, question the strength of FRP to deal with any large and repetitive impacts that the structure may possibly receive, particularly during fishing activities and moreover, when undertaking a beach landing in order to carry out repairs. The relatively light weight of FRP also becomes a weakness of the FRP fishing vessels according to some respondents. They argue that the FRP fishing vessel is too light and thus tends to be unstable for certain fishing gears. They found that it was quite difficult to control the vessel when it was setting or hauling the nets, especially when the nets are drifted by the sea current. In Brondong this situation has been exacerbated by the experiences of local fishers who have witnessed the poor quality of a number of the current FRP fishing boats, which were built rather inappropriately.

In contrast, fishers who operate smaller boats in Muncar, of up to 10 meters in length and that employed handlines or gillnets, showed an interest in FRP. The relatively light weight of the FRP boat has particularly attracted this group of fishers given that it will be physically easier for a crew of 2-3 to operate.

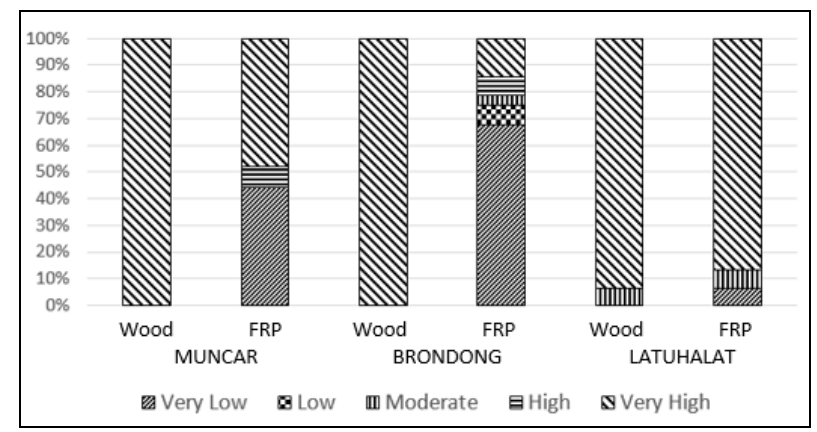

Fig. 1. Local fishers' preferences on construction material for their fishing boats 
The highest level of interest regarding FRP was found to be in Latuhalat, as seen in Figure 1. Fishers in Latuhalat have been familiar with FRP since the introduction of small FRP long boats for artisanal fishing, more than one decade ago. Subsequently, local fishers who operate larger vessels, approximately 18 meters in length, also expressed their interest in FRP, since the local fishers found that the FRP boat was more water-tight and required less maintenance when compared to the traditionally constructed wooden boat. However, according to the local respondents, the cost of constructing a FRP boat is $70 \%$ higher compared to that of building a similar sized wooden boat in Ambon. As a result, there are only a few large fishing boats made of FRP in Latuhalat.

The higher price of FRP hulled fishing vessels when compared to that of wooden fishing vessels is another issue that cause fishers to refuse FRP fishing vessels. Although there is an increase in the price of some kinds of wood recently, the cost for constructing FRP fishing vessels is still higher than the cost for constructing wooden fishing vessels, especially for the remote fishing communities. The problem of the unavailability of FRP boatyards that are close to fishing communities and the cost of the FRP components material itself causes difficulties for FRP fishing vessel to be able to compete with traditional wooden fishing vessels in term of price and availability. The availability of FRP boatyards, both builders and repairers, and the ready availability of suppliers for the FRP materials become the concern of the fishers and thus tend to make FRP fishing vessels to be less attractive compared to wooden fishing vessels since the local fishers have no personal experience and skill to maintain and repair the FRP vessels.

Based on the fishers' responses, the problems of the implementation of FRP as material for fishing vessels in Indonesia can, in general, be grouped into three problems area. The first problem area is related to the fishers' level of knowledge about this alternative material. The second problem area is related to the suitable design of the fishing vessels that could fulfil the local fishing communities' requirements and at the same time to take the advantages of FRP as being a flexible and adaptive material for fishing vessel construction. The last problem area is related to the supporting infrastructures for the implementation of FRP fishing vessels which include the FRP boatyards and the supply chain of the material. Measures to solve those problems are required to have a feasible, cost-effective, alternative solution for the construction material of fishing vessels in Indonesia.

\subsection{Future potential development}

Although the FRP's impact on the environment is still currently being questioned, since it uses fossil fuel based material, advances in the development of this material suggests it has high potential as a sustainable material for fishing vessels in Indonesia in the future. With regard to the environmental concerns and the need to minimize the negative impact of FRP on the environment, many developments have been undertaken. The development of the closed moulded system, such as Resin Transfer Moulding (RTM) or Vacuum Infusion Process (VIP), reduces styrene gaseous emission to the environment and additionally reduces negative impact on the boat-builder's health during the lamination processes [11]. The latest invention in this composite material is the using of a bio-resin to replace the previous resin that was produced from crude oil [12].

In order to promote FRP as an acceptable alternative material for fishing vessels in Indonesia, any reasonable measures to solve the problems that currently inhibit the development of FRP fishing vessels need to be carried out. One of the main reasons for the refusal of FRP for fishing vessels in Indonesia is the lack of local fishers' knowledge about this material. Any measures to increase fishers' understanding and experience about FRP material, particularly ones related to their basic skill in carrying out minor repairs on FRP 
vessels need to be developed. It is interesting to study why it is that most of the local fishers in Latuhalat, Ambon are interested in using FRP fishing vessels. These fishers have been introduced to FRP fishing vessels for years by their experience as a crew member on foreign large FRP fishing vessels. This illustrates how the fishers' earlier interactions and experiences related to FRP fishing vessels subsequently influence their current interests.

It is also important to introduce better quality of FRP fishing vessels to the local fishing communities. It is considered that the poor quality of the vessels that were initially introduced or granted to local fishers had lowered fishers' interest in FRP fishing vessels. Therefore, the availability of good quality FRP boatyards needs to be established widely in Indonesia. The Government and related parties need to develop better guidance and supervision to FRP boatyards relating to their designs, building technique and the manufacturing quality of their vessels. The usage of non-standard unqualified material by FRP boatyards, for the given reason of decreasing the building cost, should be avoided. A good supply chain for the FRP material components is also another aspect that needs to be developed. This will help local FRP boatyards to reduce their building cost, and also it will make it easier for the fishers to get the necessary material when they need it for minor repairs.

Concerning a suitable design for each size and type of FRP fishing vessel for local fishing communities, it is essential to fulfil the specific requirements of the local fishers. The designs therefore should be adapted to their fishing practices, for instance, it should fully consider the type of fishing gear that the local fishers use. Adjustment on the design and structure of the FRP fishing vessels are also required to cope with the local fishers' concerns on the strength and the rigidity of the vessels particularly in dealing with their specific fishing practices and the local geographical circumstances. The other main concern about the specific requirements of local fishing communities is related to the physical features and style that provides local identity of the fishing vessels; although it is debatable about how similar should be the basic design of the FRP fishing vessels with the local design features. In many of the fishing communities in Indonesia, a fishing vessel is not only a tool for making a living but it is also a part of the local culture and practices and has been so for ages [12]. Any changes on the local vessels will thus have further subtle consequences to local fishing communities. Therefore, an in-depth study should be undertaken in local fishing communities in which important cultural features should be identified and retained before introducing new material with a new design of the vessels for the local fishing communities. However, there is an initiative of one local boatyard in East Java that applied FRP to Maduran type traditional fishing boat without any changes on the design and ornamentations, as seen in Fig.2. It will be very interesting to observe the local fishers' responses to this new fishing boats in the next few years.

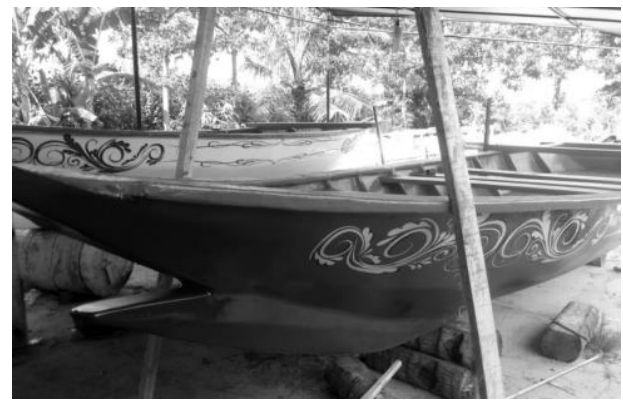

a) FRP boat (Courtesy of Mr. Putut Widodo)

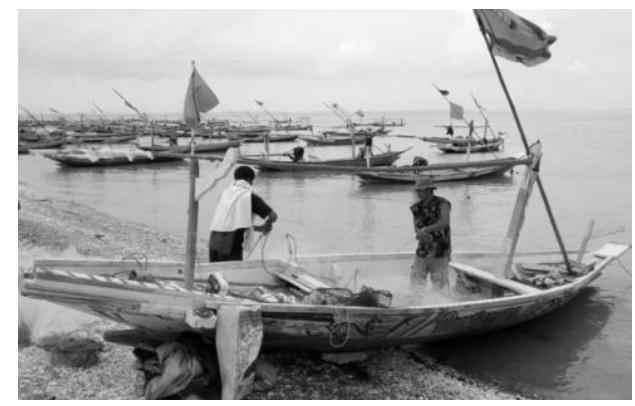

b) Wooden boat (Courtesy of www.memorandum.id)

Fig. 2. Maduran style traditional fishing boat made of wood and FRP 


\section{Conclusions}

The problem on the availability of timber as the main construction material for fishing boats in Indonesia could endanger the sustainability of the fishing fleet to support the sustainability of the fisheries sector in the future. Any measures to find suitable alternative construction material for substituting timber is required. Based on the existing development, the Fiberglass Reinforced Plastic (FRP) material is potentially the top alternative substitute to wood for building fishing vessels in Indonesia. However, further improvement and development need to be carried out to ensure that this alternative material is acceptable not only for technical aspects but also for social aspect and economical aspect. The development including improving fishers' knowledge and experience of the material, developing relevant infrastructures for the material, and developing effective designs that are both appropriate for the material and for the fishers' mode of operation. New designs should also retain visual characteristics that have cultural significance.

\section{References}

1. IMMAF, Marine and Fisheries in Figures 2015, Indonesian Ministry of Marine Affairs and Fisheries (IMMAF) (2015).

2. IMMAF, Ministerial Regulation No.45/PERMEN-KP/2015: Strategic plan for year 2015 - 2019 (in Indonesian). Indonesian Ministry of Marine Affairs and Fisheries (IMMAF) (2015).

3. I. P. A. Wibawa, Sustainable Fishing Vessel Development by Prioritising Stakeholder Engagement in Indonesian Small-scale Fisheries, PhD Thesis, Newcastle University, UK (2016)

4. A. Gudmundsson, and D. Davy, Boat-building after the tsunami: Experiences in boatbuilding in tsunami-affected countries, Bay of Bengal News, pp. 13-15, (2006)

5. D. Davy, D. Fisheries Tsunami Emergency Programme, Tsunami Reconstruction, Food and Agriculture Organization, Rome (2006)

6. IMMAF, INKA MINA, Increase fishers' profit (In Indonesian), http://kkp.go.id/index.php/arsip/c/10342/INKA-MINA-Tingkatkan-Pendapatan-Nelayan/ Retrieved 10 May 2018

7. O. Rahardjo, A. Maydino, A. Cahyo, and A. Muis, Lamination standard for FRP Fishing Vessels 3GT, J.Std 19, 3, pp.255-264 (2017)

8. R. Birmingham and I.P.A. Wibawa, The Role of Aesthetics in Engineering Design Insights Gained from Cross-cultural Research into Traditional Fishing Vessels in Indonesia, Marine Design XIII, Vol.1, Proceeding of the $13^{\text {th }}$ International Marine Design Conference (IMDC2018), Helsinki, Finland (2018)

9. J.F. Fyson, Design of Small Fishing Vessels. Farnham: Published by arrangement with the Food and Agriculture Organization Fishing News Books (1985)

10. S. Selvaraju and S.Ilaiyavel, Apllication of Composite in Marine Industries, Journal of Engineering Research and Studies, 12, 12, pp.89-91 (2011)

11. Mars, G., Material trends for FRP boats, REINFORCEDplastic, October 2003, pp.2334, (2003)

12. McAfee, R., Bio-Resin: The Future of Fiberglass, http://www.britishcolumbiayachts.com/pdfs/news_6.pdf. Retrieved 10 July 2018

13. D.M. Rosyid, and R.M. Johnson, Developing sustainable fishing vessel for developing country in the $21^{\text {st }}$ century, International conference on fishing vessel, fishing technology \& fisheries. The Royal Insitution of Naval Architects (RINA), Newcastle, UK (2005) 